\title{
Contribution of gaseous and particulate species to droplet solute composition at the Puy de Dôme, France
}

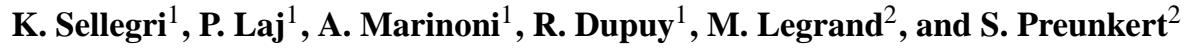 \\ ${ }^{1}$ Laboratoire de Meteorologie Physique, CNRS, Université Blaise Pascal, 24, av; des landais 63177 Aubiere cedex, France \\ ${ }^{2}$ Laboratoire de Glaciologie et Géophysique de l'Environnement, 54, rue Molière, 38402 St Martin d'Hères cedex, France
}

Received: 5 December 2002 - Published in Atmos. Chem. Phys. Discuss.: 3 February 2003

Revised: 21 August 2003 - Accepted: 2 September 2003 - Published: 26 September 2003

\begin{abstract}
Chemical reactions of dissolved gases in the liquid phase play a key role in atmospheric processes both in the formation of secondary atmospheric compounds and their wet removal rate but also in the regulation of the oxidizing capacity of the troposphere. The behavior of gaseous species and their chemical transformation in clouds are difficult to observe experimentally given the complex nature of clouds.
\end{abstract}

During a winter field campaign at the summit of the Puy de Dôme (central France, $1465 \mathrm{~m}$ a.s.l), we have deployed an experimental set-up to provide a quantification of phase partitioning of both organic $\left(\mathrm{CH}_{3} \mathrm{COOH}, \mathrm{HCOOH}, \mathrm{H}_{2} \mathrm{C}_{2} \mathrm{O}_{4}\right)$ and inorganic $\left(\mathrm{NH}_{3}, \mathrm{HNO}_{3}, \mathrm{SO}_{2}, \mathrm{HCl}\right)$ species in clouds.

We found that nitric and hydrochloric acids can be considered close to Henry's law equilibrium, within analytical uncertainty and instrumental errors. On another hand, for $\mathrm{NH}_{3}$ and carboxylic acids, dissolution of material from the gas phase is kinetically limited and never reaches the equilibrium predicted by thermodynamics, resulting in significant sub-saturation of the liquid phase. On the contrary, $\mathrm{S}^{\mathrm{IV}}$ is supersaturated in the liquid phase, in addition to the presence of significant aerosol-derived $\mathrm{S}^{\mathrm{VI}}$ transferred through nucleation scavenging.

Upon droplet evaporation, a significant part of most species, including $S^{\mathrm{IV}}$, tends to efficiently return back into the gas phase. Overall, gas contribution to the droplet solute concentration ranges from at least 48.5 to $98 \%$ depending on the chemical species. This is particularly important considering that aerosol scavenging efficiencies are often calculated assuming a negligible gas-phase contribution to the solute concentration. Our study emphasizes the need to account for the in-cloud interaction between particles and gases to provide an adequate modeling of multiphase chemistry systems and its impact on the atmospheric aerosol and gas phases.

Correspondence to: $\mathrm{K}$. Sellegri

(k.sellegri@mpi-hd.mpg.de)

\section{Introduction}

The chemical composition of cloud droplets results from chemical and physical processes that include the dynamics of cloud formation, the composition and concentration of the aerosols that served as CCN (nucleation and impaction scavenging), the transfer of volatile species across the air/water interface during the cloud lifetime and the chemical reactions that can take place in the liquid phase. The transfer efficiency to the condensed phase has considerable impact on the lifetime of some chemical substances as well as on oxidant levels in the troposphere (Lelieveld and Crutzen, 1991, Lawrence and Crutzen, 1998). The most efficient mechanisms that control the solute composition and concentration in cloud drops are nucleation scavenging for particles and gas-liquid equilibrium for gases. Nucleation scavenging of particles is often described by the Koehler theory: an aerosol particle will or will not be activated to a cloud drop according to its diameter and chemical composition and to the super-saturation of water vapour (Pruppacher and Klett, 1997). This theory, however, appears to be limited to properly describe the activation of organic aerosol particles in particular in the presence of either slightly soluble compounds that dissolve at super-saturation lower than $1 \%$ or of elevated concentrations of soluble gases that can depress the water vapour pressure on the droplet surface, shifting the activation radius at a given R.H. towards smaller particles (Kulmala et al., 1995). At present, prediction of the number of $\mathrm{CN}$ serving as cloud condensation nuclei $(\mathrm{CCN})$ under given super-saturation is therefore highly uncertain. Generally, between 50 and $90 \%$ of particle mass is scavenged into cloud drops through nucleation corresponding to 10 to $90 \%$ of the particle number. After condensation of water onto the particle is initiated, the growth of the cloud droplet results in solute concentrations that tend to decrease due to diffusional growth after droplet activation (Ogren et al., 1992; Ogren and Charlson, 1992; Flossmann et al., 1998; Flossmann, 
1994). Consequently, a large variability of solute concentration in cloud droplets arises from different environmental conditions.

The scavenging of gases is often estimated by considering Henry's law equilibrium existing between the different phases of the system between gas and aqueous phases for both aerosols and cloud droplets (Warneck, 1986, Schwartz, 1986, Lelieveld and Crutzen, 1991). This assumption, however, does not appear to be fully supported by experimental studies in fog and cloud systems. Deviations from theoretical equilibrium of several orders of magnitude have been found for gases such as $\mathrm{SO}_{2}, \mathrm{NH}_{3}$ or $\mathrm{HCOOH}$, showing either sub- or super-saturation of the liquid phase of clouds (Facchini et al., 1992a; Facchini et al., 1992b; Keene et al., 1995; Laj et al., 1997; Munger et al., 1995; Noone et al., 1991; Rao and Collett, 1995; Richards et al., 1983; Winiwarter et al., 1988; Winiwarter et al., 1994). Such deviations are not easily explained neither by additional equilibrium nor by in-cloud formation of new compounds (Winiwarter et al., 1994), nor by sampling artifact due to long integration time or droplet heterogeneity (Ricci et al., 1998, Pandis and Seinfeld, 1991; Winiwarter et al., 1992). Mass-transfer limitation across the droplet interface (Schwartz, 1986), sampling cloud water during temporary clear-air breaks, inadequate description of cloud dynamics (Audiffren et al., 1996) and/or analytical uncertainties may also result in significant deviations from equilibrium. It is therefore important to assess the extent to which the departures observed at different sites represent the actual behaviour of chemical compounds in clouds and to quantify the possible implications of nonequilibrium for the cloud processing of chemical species in the atmosphere. Overall, it is estimated that uncertainty in describing the equilibrium can lead to significant errors in estimating wet deposition of soluble gases (Lawrence and Crutzen, 1998).

Because the rates of chemical transfer from both nucleation scavenging and gas-liquid equilibrium are often highly uncertain, estimating the solute composition and concentration is not straightforward. Moreover, it is also difficult to estimate the relative contribution of each process to the resulting solute composition. Knowledge of this information, however, is valuable not only to contribute to the understanding of the chemical cycling of key atmospheric species but also to validate multiphase atmospheric models. In past literature, these two mechanisms are often considered independently from each other to derive estimates of scavenging efficiencies. For example, the gas contribution to droplet concentration is commonly calculated under the assumption that all material from particles larger then a specific critical particle size is scavenged, as a result of the application of the Koehler theory on an internally mixed aerosol (Krämer et al., 2000; Husain et al. 2000). On the contrary, aerosol particle scavenging efficiencies are calculated by comparing droplet and interstitial aerosol concentrations and assuming negligible contribution of gases in the cloud droplets (Hitzen- berger et al., 2000 ; Kasper-Giebl et al., 1999; Kasper-Giebl et al., 2000; Limbeck and Puxbaum, 2000). In the present paper, we propose an experimental methodology to de-couple contributions from gaseous and particulate phase to the solute composition and concentration in cloud samples. The methodology is applied to the study of multiphase systems at the observation site of Puy de Dôme (Central France) to estimate the phase partitioning of sulfur, ammonia, nitrate, carboxylic and dicarboxylic acids between gas and condensed phases and discuss the particulate and gaseous contributions to the ionic concentration in cloud droplets.

\section{Experimental methodology}

\subsection{Sampling strategy}

The experimental strategy is based on separated sampling of the different cloud reservoirs, coupled with accurate measurements of cloud microphysics (Fig. 1).

- The Counterflow Virtual Impactor (CVI) is based on the principle of the inertial sampling of droplets in a counter-flow of pure and dry air (Ogren et al., 1985). The size cut of the instrument is evaluated to $4-5 \mu \mathrm{m}$ by a set of laboratory, in-situ and modeling calibration experiments (Vocourt, 2002). Thus, all interstitial gases and deliquesced aerosols which diameter is smaller than $5 \mu \mathrm{m}$ are rejected while all droplets larger then $5 \mu \mathrm{m}$ (hereafter referred as cloud droplets) are admitted into the probe. Droplets selected by the CVI are then heated to $25^{\circ} \mathrm{C}$ and thereby evaporated into residual particles. Residual particles are sampled using a 12-stage lowpressure cascade impactor (SDI $11 \mathrm{l} / \mathrm{min}$ ), with cut size diameters of $0.045,0.086,0.153,0.231,0.343,0.591$, $0.796,1.060,1.66,2.68,4.08,8.39 \mu \mathrm{m}$.

- The Round Jet Impactor (RJI) is a one-stage impactor with a $50 \%$ cut-off close to $5 \mu \mathrm{m}$ (Wobrock et al., 2001). While all deliquesced particles and droplets larger than $5 \mu \mathrm{m}$ are impacted on a front plate and then evacuated, particles smaller than $5 \mu \mathrm{m}$ (hereafter referred as interstitial particles) and interstitial gases are allowed into the probe. Interstitial particles are then sampled using 13-stage low-pressure cascade impactor (ELPI $301 / \mathrm{min}$ ), with cut size diameters of $0.030,0.060$, $0.108,0.17,0.26,0.40,0.65,1.0,1.60,2.5,4.4,6.8$ and $9.9 \mu \mathrm{m}$. The sampled air was filtered using Teflon $0.2 \mu \mathrm{m}$ porosity filters before entering the mist chambers, at flow rates of $10 \mathrm{l} / \mathrm{min}$. Interstitial gases are then sampled with a modified version of the mist chamber (MC) technique (Talbot et al., 1997). Soluble gases are absorbed on mist droplets created by a capillary in a sampling glass vessel. The sampling system was composed of two separate mist chambers in order to enhance 


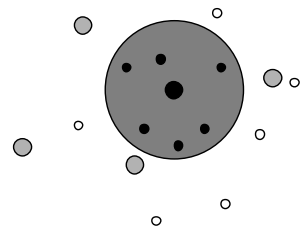

\section{Cloud Droplet Impactor (CDI)}

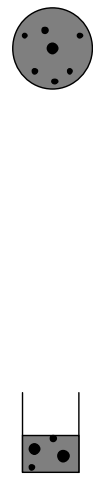

Bulk

liquid phase

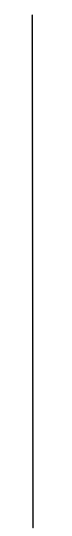

\section{Counterflow Virtual Impactor (CVI)}

Droplets $(\mathrm{Dp}>5 \mu \mathrm{m})$

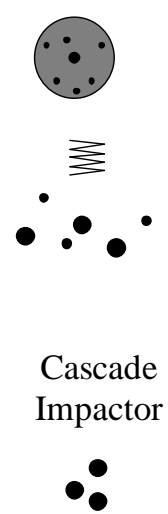

Residual particles

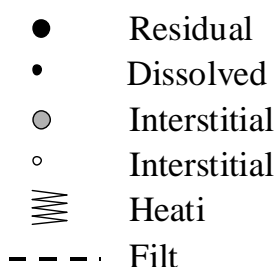

\section{Round Jet Impactor (RJI)}

$$
\mid
$$

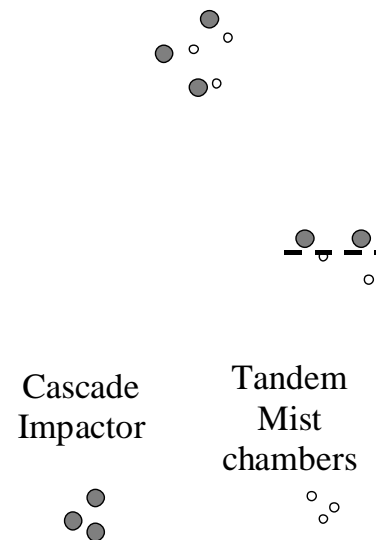
Interstitial particles

Fig. 1. Experimental set up for sampling the different cloud reservoirs.

the collection efficiency of each component (tandem mist chambers unit).

- Droplets can also be sampled using a one stage Cloud Droplet Impactor (CDI) adapted for high wind speeds, similar to that used by Kruisz et al. (1993) with a $50 \%$ cut-off at $7 \mu \mathrm{m}$. Complementary to the CVI this sampler collects the bulk liquid phase and can be compared to the particulate residuals for the retrieval of dissolved gases. The liquid-phase concentrations $\left(\mu \mathrm{mol} \mathrm{l}_{\text {water }}^{-1}\right)$ can be converted to atmospheric concentrations ( $\mathrm{nmol} \mathrm{m}_{\text {air }}^{-3}$ ) using an integrated value of LWC over the sampling duration. This makes comparison with other cloud reservoirs much easier. For this purpose, LWC is measured with a Gerber probe PVM-100 installed in a wind tunnel of the station, with a precision of about $20 \%$.

These three devices (i.e. CVI, RJI and CDI) are operated at ambient temperature, which preserves the atmospheric phase partitioning. Only after being separated by these devices, the different cloud phases are sampled with cascade impactors and mist chambers at room temperature (less than $10^{\circ} \mathrm{C}$ difference between room and outside temperature).

Depending on the air temperature, the liquid phase sampled with the Cloud Droplet Impactor was either found in the liquid state on the impacting collector or in the frozen state (after contact freezing of super-cooled droplets). The water was transferred either directly or after short melting into glass vials. All manipulations were performed under a horizontal laminar flow bench equipped with an additional activated charcoal filter to limit interaction of substrates with $\mathrm{HNO}_{3}$ or $\mathrm{NH}_{3}$ vapors possibly present in the room. Most samples were collected during super-cooled conditions. Upon freezing, a fraction of the gas dissolved in the super-cooled droplets is transferred back to the gas phase while another is retained in the ice matrix. The retention coefficient is defined as the fraction remaining in the ice. There is still a lot of uncertainty on the retention coefficient even 
for the most common atmospheric gases. A low retention coefficient would lead to an underestimation of the gaseous concentrations in super-cooled water. However, the retention coefficient observed by Voisin et al. (2000) for $\mathrm{HNO}_{3}, \mathrm{HCl}$ and $\mathrm{NH}_{3}$ is close to 1 . This is confirmed by the fact that samples collected during warm events do not show higher condensed-to-gas phase ratios than the other samples. We do not have any information on retention coefficients for organic acids.

Because the methodology is based on comparing different instrumentations connected to different inlets, it is important to discuss the possible sampling artifacts and errors. Errors can occur from uncertainty on the flow rates, as well as artifacts due to losses or modifications of particles or gazes during sampling. Because it is difficult to directly estimate these artifacts, we will estimate the consistency of our sampling set up from the comparisons of results from each device for specific conditions.

- CVI/RJI: the complementarities of these two devices can be checked with a third inlet sampling both interstitial and residual phases (Whole Air Inlet, WAI). All phases of the multiphase system are sampled into a stainless-steel duct. A windshield that lowers air speed around the air inlet increases the duct sampling efficiency. All parts of the inlet are heated to avoid ice formation when temperatures are near or lower than $0^{\circ} \mathrm{C}$. Sampled droplets are gently evaporated maintaining a relative humidity between 40 and $60 \%$ in the duct regardless of the outside conditions. During clear sky conditions, aerosols sampled in the WAI are in agreement with the aerosols sampled in the RJI within $15 \%$. Also, during clear sky conditions, no aerosols are sampled with the CVI

- CVI/CDI: Slight differences exist between the cut-off sizes of the CVI and the CDI $(5 \mu \mathrm{m}$ for CVI and $7 \mu \mathrm{m}$ for $\mathrm{CDI}$ ), thus an underestimation of the liquid-phase concentration can arise in the CDI due to the fact that small droplets are generally more concentrated than larger ones (Laj et al., 1998; Schell et al., 1997). However, on average, in a typical cloud droplet spectrum at puy de Dome, the water mass comprised between 5 and $7 \mu \mathrm{m}$ is lower than $5 \%$ of the total mass. Under these conditions, and assuming that smaller droplets $(<7 \mu \mathrm{m})$ are $20 \%$ more concentrated than larger ones (Schell et al., 1997), this would lead to a difference in concentration of the order of $6 \%$ between droplet concentration sampled in the CVI and in the CDI. To overcome the problem of confronting absolute concentrations of species obtained from instruments which conceptions differ fundamentally, we often based the discussion on relative rather than absolute differences. As will be seen later, absolute concentration ratios involving CVI and CDI match ratios of concentrations relative to a reference compound (CVIref, CDIref) within 0.3 to $30 \%$, depending on the species (see Table 6). This gives us an upper limit for the total uncertainty on these measurement ratios (including flow rate, analytical uncertainties, and respective sampling efficiencies).

Finally, absolute uncertainties on MC and IB measurements are needed to give a range of measured gas/liq partitioning. From laboratory calibrations using permeation tubes and inter-comparisons between two sets of tandem-MC, uncertainty on the gas measurements is estimated to $50 \%$ on average, with higher uncertainty for compounds at low concentrations such as nitric and oxalic acid, volatile chloride and $\mathrm{SO}_{2}$ (up to $75 \%$ ). We do not have any absolute calibration of the CDI measurements, because of the difficulty of estimating the sampling efficiency according to different speed and direction of wind during sampling. From the comparison of CDI sample and CVI sample stated above and uncertainty on CVI samples (15\%), we estimate the uncertainty on CDI measurements to $30 \%$.

\subsection{Field site and meteorological conditions}

Sampling was performed between 8 February and 1 March 2001 at the summit of the Puy de Dôme $\left(48^{\circ} \mathrm{N} 2^{\circ} \mathrm{E}\right.$, $1465 \mathrm{~m}$ a.s.1.), France. Prevailing western winds allowed for the sampling of oceanic air masses, which had evolved over $250 \mathrm{~km}$ of land, and whose characteristics are typical of a free-troposphere site during wintertime. Local contamination at the site is extremely limited in winter, since the access to the station is restricted to authorized personnel. The site, detailed in Wobrock et al. (2001), is part of several measuring networks that provide information on concentrations of several gases as well as on particle levels. It is equipped for meteorological and cloud microphysical measurements.

In this paper, we will report information from five different cloud events. An overview of the measurements of interest to this study is given in Table 1 .

\subsection{Chemical analyses}

Polycarbonate filters $(0.2 \mu \mathrm{m}$ pore size $)$ were used as impaction substrates. They were not coated in order to eliminate analytical complexities associated with the use of grease. Bouncing of particles from one stage to another is limited due to the low concentration of particles (especially in the super-m range) and the sampling RH maintained between 40 and $60 \%$. Samples were stored in individual tight Petri dishes and kept frozen until analysis. About 15 blank samples were performed on a regular basis by loading the impactors in the field and performing extraction and chemical analyses similar to those performed for regular samples. Filter extraction and ion chromatography analyses were performed inside a Class 1000 clean room to prevent from external contamination. Polycarbonate filters were extracted in ultrapure water by 15 minutes soaking, while MC and CDI samples already in the water phase did not undergo any 
Table 1. Sampling conditions. Most cloud water samples were taken during super-cooled conditions. Variability is calculated as standard deviations amongst samples of a cloud event

\begin{tabular}{|c|c|c|c|c|c|c|}
\hline $\begin{array}{l}\text { Impactor } \\
\text { sample }\end{array}$ & Date/hour & $\begin{array}{l}\text { Number of } \\
\text { CDI samples }\end{array}$ & $\begin{array}{l}\text { Number of } \\
\text { MC sample }\end{array}$ & $\begin{array}{c}\text { Mean LWC } \\
\left(\mathrm{g} \mathrm{m}^{-3}\right)\end{array}$ & Temperature $\mathrm{K}$ & $\begin{array}{c}\text { Average } \mathrm{H}^{+} \\
\text {converted to } \\
\text { pH (CDI) }\end{array}$ \\
\hline 1 & $\begin{array}{l}12 / 02 \text { 22 h } 10 \\
14 / 0210 \mathrm{~h} 00\end{array}$ & 9 & 6 & $0.37 \pm 0.17$ & $272,7 \pm 1.2$ & $4.6 \pm 0.5$ \\
\hline 2 & $\begin{array}{l}17 / 0212 \mathrm{~h} 40 \\
18 / 0210 \mathrm{~h} 00\end{array}$ & 11 & 2 & $0.44 \pm 0.09$ & $268.2 \pm 0.6$ & $4.1 \pm 0.5$ \\
\hline 3 & $\begin{array}{l}22 / 0215 \text { h } 36 \\
23 / 0211 \text { h } 45\end{array}$ & 10 & 4 & $0.29 \pm 0.08$ & $271.8 \pm 1.05$ & $5.5 \pm 0.3$ \\
\hline 4 & $\begin{array}{l}23 / 0215-20 h \\
24 / 0202-06 h\end{array}$ & 8 & 1 & $0.27 \pm 0.05$ & $270.3 \pm 2.1$ & $5.7 \pm 0.1$ \\
\hline 5 & $\begin{array}{l}28 / 0200 \text { h } 15 \\
01 / 0310 \text { h } 00\end{array}$ & 10 & 3 & $0.15 \pm 0.06$ & $267.4 \pm 0.3$ & $4.2 \pm 0.4$ \\
\hline
\end{tabular}

Table 2. Atmospheric detection limits calculated as twice the standard deviation on blanks for a typical $25 \mathrm{~m}^{3}$ sample for impactor data, for a typical $0.3 \mathrm{~g} \mathrm{~m}^{-3} \mathrm{LWC}$ for CDI data; and for a typical one hour long sampling time for MC data

\begin{tabular}{cccccccc}
\hline $\mathrm{Nmol} \mathrm{m}^{-3}$ & Ace & For & $\mathrm{HCl} / \mathrm{Cl}^{-}$ & $\mathrm{HNO}_{3} / \mathrm{NO}_{3}^{-}$ & $\mathrm{SO}_{4}^{2-}$ & $\mathrm{Ox}$ & $\mathrm{NH}_{3} / \mathrm{NH}_{4}^{+}$ \\
\hline Aerosol & 0.28 & 0.15 & 1.1 & 0.35 & 0.30 & 0.02 & 0.4 \\
Liquid & 0.049 & 0.038 & 0.07 & 0.11 & 0.14 & 0.006 & 0.21 \\
Gas & 0.30 & 0.38 & 2.0 & 0.42 & 0.52 & 0.22 & 5.7 \\
\hline
\end{tabular}

pretreatment before analysis. All samples were analyzed by Ion Chromatography using a DIONEX 100 chromatograph, equipped with a CS12 column for cations, and with a DIONEX 500 chromatograph, column AS11 for anions. Analyzed species of interest are $\mathrm{CH}_{3} \mathrm{COO}^{-}, \mathrm{HCOO}^{-}, \mathrm{Cl}^{-}$, $\mathrm{NO}_{3}^{-}, \mathrm{SO}_{4}^{2-}, \mathrm{Ox}^{-}\left(\mathrm{C}_{2} \mathrm{O}_{4}^{2-}\right), \mathrm{Na}^{+}$and $\mathrm{NH}_{4}^{+} . \mathrm{MSA}^{-}, \mathrm{NO}_{2}^{-}$, $\mathrm{K}^{+}, \mathrm{Mg}^{2+}$ and $\mathrm{Ca}^{2+}$ are also analyzed in order to derive the $\mathrm{H}^{+}$concentration from the ionic balance. Further details on the analytical procedure are given in Jaffrezo et al. (1998). The precision of the analytical method is evaluated to $10 \%$ for samples ten times the detection limit of ion chromatograph (based on analytical water blanks) and around 50\% for samples less than two times its detection limit. Atmospheric detection limits are derived from the analysis of blank values and defined as twice the standard deviation on blank for particulate, liquid and gaseous samples. The mass concentration of particles was calculated by summing all impactor stages. Thus detection limits for bulk particulate concentrations were the sum of the detection limits for individual impactor stages, which are given in Table 2 for a typical sampling volume of $25 \mathrm{~m}^{3}$ for impactor data, for a typical $0.3 \mathrm{~g} / \mathrm{m}^{3} \mathrm{LWC}$ for CDI data; and for a typical one hour long sampling time for MC data.

While $\mathrm{S}^{\mathrm{IV}}$ species $\left(\mathrm{HSO}_{3}^{-}+\mathrm{SO}_{3}^{2-}\right)$ are transferred from the gas to the liquid phase during mist chamber measurements, they are analyzed as $\mathrm{SO}_{4}^{2-}$. The implicit assumption is that all $\mathrm{S}^{\mathrm{IV}}$ is oxidized to $\mathrm{S}^{\mathrm{VI}}$ in the liquid samples waiting or during chemical analysis. Because the liquid phase is analyzed several hours after sampling and despite the fact that samples are kept frozen, oxidation can proceed either via reaction with $\mathrm{O}_{3}$ or $\mathrm{H}_{2} \mathrm{O}_{2}$ resulting in complete $\mathrm{S}^{\mathrm{IV}}$ oxidation. This is confirmed by the absence of $\mathrm{SO}_{3}^{-}$in the samples and previous comparison between artificially oxidized and non-oxidized mist chamber samples (Voisin et al., 2000). However, some traces of $\mathrm{S}^{\mathrm{IV}}$ can still be present in the liquid phase, and $\mathrm{SO}_{2}$ concentrations measured in this work are lower limits. The same problem is encountered in CDI samples, where $\mathrm{SO}_{4}^{2-}$ is measured as the sum of $\mathrm{S}^{\mathrm{IV}}$ and $\mathrm{S}^{\mathrm{VI}}$ species. On the basis of the total oxidation of $S^{I V}$ species in CDI samples, and volatilization of dissolved $\mathrm{S}^{\mathrm{IV}}$ during the evaporation of cloud droplets in the CVI, we evaluate $\mathrm{S}^{\mathrm{IV}}$ species in CDI samples with the following calculation:

$\mathrm{S}_{\mathrm{CDI}}^{\mathrm{IV}}=\mathrm{S}_{\mathrm{CDI}}^{\mathrm{VI}}-\mathrm{S}_{\mathrm{CVI}}^{\mathrm{VI}}$

The hypothesis that in our set up, at least a fraction of the $\mathrm{S}^{\mathrm{IV}}$ dissolved in cloud droplets is oxidized (after sampling) in the bulk samples from the CDI but evaporates in the CVI will later be confirmed from measurements (Sect. 3.3).

Recent studies have questioned the use of mist chambers for the determination of $\mathrm{HNO}_{3}$ and volatile inorganic $\mathrm{Cl}$ concentrations due to their ability to stick to tubing and glassware (Neuman et al., 1999). The comparison of MC and denuders by Voisin et al. (2000) shows a reasonable agreement for all species except $\mathrm{HNO}_{3}$ which was two times higher in 
the denuder tubes than in the MC. Consequently, the interstitial gas fraction presented in this paper might be underestimated, from being sampled with mist chambers. The gas fractions of the total mass are thus lower limits also for these two species.

\section{Results}

\subsection{Chemical composition of cloud phases}

\subsubsection{Liquid Phase of droplets}

This section will deal with concentrations measured in the liquid phase sampled with the CDI, i.e. droplets $>7 \mu \mathrm{m}$. $\mathrm{SO}_{4}^{2-}, \mathrm{NH}_{4}^{+}$, and $\mathrm{NO}_{3}^{-}$account for more than $80 \%$ of the total analyzed mass of ions while chloride and carboxylic acids account for 8 and 9\%, respectively (arithmetic average). Sulfate concentrations range from 4 to $40 \mu \mathrm{moll}^{-1}$, which is very similar to levels found in clouds at most of the European altitude sites: between 27 to $70 \mu \mathrm{mol}^{-1}$ measured at Mt Sonnblick (Hitzenberger et al., 2000), Mt Jungfraujoch (Baltensperger et al., 1998) and Kleiner Feldberg (Wobrock et al., 1994). The maximum values are an order of magnitude lower than concentrations measured at Puy de Dôme during the CIME 1998 experiment and at Great Dun Fell, (360 and $240 \mu \mathrm{mol}^{-1}$ respectively, Laj et al., 2001; Laj et al., 1997). Similar considerations can be made for $\mathrm{NH}_{4}^{+}$and $\mathrm{NO}_{3}^{-}$concentrations $\left(28-150 \mu \mathrm{moll}^{-1}\right.$ and $12-93 \mu \mathrm{moll}^{-1}$ respectively), comparable to the concentrations measured at Kleiner Feldberg ( $180 \mu \mathrm{mol} \mathrm{l}^{-1}$ for both species; Wobrock et al. 1994), but an order of magnitude higher than those measured at Jungfraujoch (16 and $10 \mu \mathrm{moll}^{-1}$; Baltensperger et al., 1998), and an order of magnitude lower than the those measured at the Puy de Dôme or Great Dun Fell (90$2000 \mu \mathrm{moll}^{-1}$ for $\mathrm{NH}_{4}^{+}$and 5-1000 $\mu \mathrm{moll}^{-1}$ for $\mathrm{NO}_{3}^{-}$; Laj et al 2001; Laj et al, 1997).

Concentrations shown in Table 3 have been converted from liquid concentrations to atmospheric concentrations; they vary over large ranges (Table 3). Most samples are slightly acidic with a median cation/anion equivalent ratio of $0.88 \pm 0.16$, as expected from previous measurements at PDD (Flossmann et al., 2000). The $\mathrm{NO}_{3}^{-} / \mathrm{SO}_{4}^{2-}$ equivalent ratio ranges from 1.1 to 2.1, which is close to those reported by Fuzzi et al. (1994) for the Kleiner Feldberg (equivalent ratio of the order of 1-2). Two samples, corresponding to two fractions of the same cloud event, are basic.

\subsubsection{Particulate droplet residuals}

The chemical composition of droplet particulate residuals measured during the five cloud events, calculated as the sum of all impactor stages, is given in Table 3. Because the chemical and physical properties of the aerosol at Puy de Dôme are discussed in details in Sellegri et al. (2003a), we will here restrict the discussion to issues related to multiphase chemistry of clouds. As expected, most of the mass ( $>90 \%)$ consists of $\mathrm{NH}_{4}^{+}, \mathrm{SO}_{4}^{2-}$, and $\mathrm{NO}_{3}^{-}$. The contribution of carboxylic acids is lower than $2 \%$ of the total ionic mass while that of $\mathrm{Cl}^{-}$ is less than 5\%. The $\mathrm{Cl}^{-} / \mathrm{Na}^{+}$ratio in the droplet residuals is lower than in the liquid phase. This confirms that most of the $\mathrm{Cl}^{-}$originally in the liquid phase volatilizes back to the gas phase upon droplet evaporation. As for $\mathrm{Cl}^{-}$and organic acids, the contribution of $\mathrm{NO}_{3}^{-}$with respect to $\mathrm{SO}_{4}^{2-}$ is often proportionally higher in the liquid phase than in the residual particles, showing significant contribution of the gas phase.

\subsubsection{Interstitial gaseous phase}

Because sampling is performed in clouds, the presence of gas molecules in the interstitial air results from both their original concentration before cloud formation and their ability to dissolve in cloud droplets. The concentrations are dominated by $\mathrm{NH}_{3}, \mathrm{HCOOH}$, and $\mathrm{CH}_{3} \mathrm{COOH}$ while concentrations of $\mathrm{HCl}, \mathrm{SO}_{2}, \mathrm{HNO}_{3}, \mathrm{C}_{2} \mathrm{O}_{4} \mathrm{H}_{2}$ never exceed $20 \mathrm{nmol} \mathrm{m}^{-3}$ but for $\mathrm{HCl}$ in one sample, and are often below detection limits (Table 3). This is similar to other measurements performed in clouds showing lower interstitial concentrations of $\mathrm{HNO}_{3}$ compared to interstitial concentrations of organic acids (Facchini et al., 1992a ; Fuzzi et al., 1994). Also, the interstitial concentration of $\mathrm{NH}_{3}$ is variable depending on the intensity of the agricultural source (Facchini et al., 1992; Fuzzi et al., 1994).

Voisin et al. (2000) performed similar measurements at Puy de Dôme by during the winter 1998 (CIME experiment) using the $\mathrm{MC}$ technique. Concentrations are in the same range for $\mathrm{HCOOH}, \mathrm{CH}_{3} \mathrm{COOH}$ and $\mathrm{HCl}$. However, our measurements show higher concentrations of $\mathrm{NH}_{3}$ and lower for $\mathrm{HNO}_{3}$ and $\mathrm{SO}_{2}$.

\subsubsection{Interstitial aerosol phase}

Interstitial aerosol particles composition is calculated as the sum of impactor stages. They are mostly composed of the major ions $\mathrm{SO}_{4}^{2-}, \mathrm{NO}_{3}^{-}$and $\mathrm{NH}_{4}^{+}$, but their concentrations are one order of magnitude lower than in the residual phase (Table 3), indicating efficient nucleation scavenging (Sellegri et al., 2003b). Concentrations of organic acids are often below detection limits and those of $\mathrm{Cl}^{-}$do not get higher than $0.4 \mathrm{nmol} \mathrm{m}^{-3}$. In addition to the reduced mass of inorganic compounds left in the interstitial phase, there is a clear depletion of $\mathrm{NO}_{3}^{-}$compared to residual and liquid phases. This can be seen comparing $\mathrm{NO}_{3}^{-} / \mathrm{SO}_{4}^{2-}$ and $\mathrm{NH}_{4}^{+} / \mathrm{NO}_{3}^{-}$ratios in interstitial, residual and liquid phases. At the Puy de Dôme, processing of aerosols mostly deals with gas-to-particle conversion of $\mathrm{HNO}_{3}$ rather than oxidation of $\mathrm{S}^{\mathrm{IV}}$ to $\mathrm{S}^{\mathrm{VI}}$. Consequently, $\mathrm{HNO}_{3}$ would not only contribute to acidification of the cloud droplets but also of the residual aerosols. On the contrary, no clear difference is measured between the proportions of $\mathrm{NH}_{4}^{+}$and $\mathrm{SO}_{4}^{2-}$ in interstitial and residual phases. 
Table 3. (a) Atmospheric concentration (in $\mathrm{nmol} \mathrm{m}^{-3}$ ) in the liquid phase of clouds measured with the CDI. Samples are averaged over the entire period of the cloud event and corrected for $\mathrm{LWC}$ to convert from $\mathrm{ng} \mathrm{l}^{-1}$ to nmol $\mathrm{m}^{-3}, \mathrm{~S}^{\mathrm{IV}}$ is calculated as [SO $\left.{ }_{4}^{2-} \mathrm{CDI}-\mathrm{SO}_{4}^{2-} \mathrm{CVI}\right](\mathbf{b})$ Residual aerosol concentrations (in nmol m${ }^{-3}$ ), as the sum of all impactor stages (c) Interstitial aerosol concentrations (in $\mathrm{nmol} \mathrm{m}^{-3}$ ), as the sum of all impactor stages (d) Concentration of gaseous species (in nmol m${ }^{-3}$ ) in the interstitial phase of clouds. Ionic ratios are calculated in eq $\mathrm{m}^{-3}$

\begin{tabular}{|c|c|c|c|c|c|c|c|c|c|}
\hline \multicolumn{10}{|c|}{ (a) Liquid concentrations of droplets (CDI samples) } \\
\hline Event & $\mathrm{CH}_{3} \mathrm{COO}^{-}$ & $\mathrm{HCOO}^{-}$ & $\mathrm{Cl}^{-}$ & $\mathrm{NO}_{3}^{-}$ & $\mathrm{SO}_{4}^{2-}$ & $\mathrm{C}_{2} \mathrm{O}_{4}^{2-}$ & $\mathrm{NH}_{4}^{+}$ & $\mathrm{NH}_{4}^{+} / \mathrm{SO}_{4}^{2-}$ & $\mathrm{NO}_{3}^{-} / \mathrm{SO}_{4}^{2-}$ \\
\hline 1 & $0.97 \pm 1.16$ & $1.1 \pm 1.4$ & $5.9 \pm 5.5$ & $10.4 \pm 10.5$ & $3.1 \pm 2.4 \mathrm{~S}^{\mathrm{IV}}=1.2$ & $0.18 \pm 0.17$ & $11.6 \pm 11.2$ & 1.8 & 1.7 \\
\hline 2 & $2.2 \pm 0.96$ & $2.3 \pm 1.1$ & $9.3 \pm 9.2$ & $85.6 \pm 63.7$ & $20.4 \pm 6.3 \mathrm{~S}^{\mathrm{IV}}=8$ & $0.65 \pm 0.15$ & $62.5 \pm 12.2$ & 1.5 & 2.1 \\
\hline 3 & $0.62 \pm 0.57$ & $0.64 \pm 0.7$ & $0.44 \pm 0.3$ & $4.0 \pm 3.2$ & $1.1 \pm 0.3 \mathrm{~S}^{\mathrm{IV}}=0.22$ & $0.13 \pm 0.12$ & $7.4 \pm 4.15$ & 3.5 & 1.9 \\
\hline 4 & $1.7 \pm 0.78$ & $1.8 \pm 0.9$ & $7.8 \pm 7.4$ & $13.9 \pm 10.9$ & $6.2 \pm 5.5 \mathrm{~S}^{\mathrm{IV}}=2.8$ & $0.26 \pm 0.09$ & $20.3 \pm 10.3$ & 1.6 & 1.1 \\
\hline 5 & $1.5 \pm 2.1$ & $1.0 \pm 1.0$ & $4.0 \pm 3.8$ & $14.3 \pm 13.4$ & $5.2 \pm 3.6 \mathrm{~S}^{\mathrm{IV}}=2$ & $0.25 \pm 0.2$ & $14.3 \pm 10.1$ & 1.4 & 1.4 \\
\hline \multicolumn{10}{|c|}{ (b) Residual aerosol particulate concentrations (CVI+cascade impactor samples) } \\
\hline 1 & $<\mathrm{dl}$ & 0.02 & 0.43 & 6.0 & 1.9 & 0.07 & 5.9 & 1.6 & 1.6 \\
\hline 2 & 0.10 & 0.17 & 0.86 & 26.3 & 12.4 & 0.20 & 26.2 & 1.1 & 1.1 \\
\hline 3 & $<\mathrm{dl}$ & $<\mathrm{dl}$ & 0.51 & 3.5 & 0.88 & 0.09 & 6.0 & 3.4 & 2 \\
\hline 4 & 0.03 & $<\mathrm{dl}$ & 3.3 & 8.0 & 3.4 & 0.11 & 12.1 & 1.8 & 1.2 \\
\hline 5 & 0.03 & 0.03 & 0.51 & 4.7 & 3.2 & 0.08 & 7.4 & 1.2 & 0.7 \\
\hline \multicolumn{10}{|c|}{ (c) Interstitial aerosol particulate concentrations (RJI+cascade impactor samples) } \\
\hline 1 & $<\mathrm{dl}$ & $<\mathrm{dl}$ & $<\mathrm{dl}$ & 0.61 & 0.52 & 0.05 & 1.3 & 1.3 & 0.6 \\
\hline 2 & $<\mathrm{dl}$ & 0 & 0.14 & 1.7 & 1.2 & 0.07 & 4.2 & 1.8 & 0.7 \\
\hline 3 & $<\mathrm{dl}$ & 0.08 & $<\mathrm{dl}$ & 0.68 & $=\mathrm{dl}$ & 0.05 & 1.1 & - & - \\
\hline 4 & 0.032 & $<\mathrm{dl}$ & 0.36 & 1.32 & 1.1 & 0.09 & 3.4 & 1.5 & 0.6 \\
\hline 5 & $<\mathrm{dl}$ & 0.24 & 0.17 & 1.0 & 0.47 & 0.09 & 1.0 & 1.1 & 1.1 \\
\hline \multicolumn{10}{|c|}{ (d) Interstitial gaseous concentrations (RJI+mist chamber samples) } \\
\hline Event & $\mathrm{CH}_{3} \mathrm{COOH}$ & $\mathrm{HCOOH}$ & Volatile $\mathrm{Cl}$ & $\mathrm{HNO}_{3}$ & $\mathrm{SO}_{2}$ & $\mathrm{H}_{2} \mathrm{C}_{2} \mathrm{O}_{4}$ & $\mathrm{NH}_{3}$ & & \\
\hline 1 & $11 \pm 13$ & $5.8 \pm 3.9$ & $5.7 \pm 5.1$ & $0.74 \pm 0.5$ & 0.60 & 0.28 & $18 \pm 6.7$ & & \\
\hline 2 & $17 \pm 3.6$ & $7.0 \pm 0.4$ & $<\mathrm{dl}(0.74)$ & $<\mathrm{dl}(0.39)$ & 0.60 & $<\mathrm{dl}(0.16)$ & $39 \pm 8.8$ & & \\
\hline 3 & $7.6 \pm 2.8$ & $3.9 \pm 1.2$ & $<\mathrm{dl}(0.14)$ & $<\mathrm{dl}(0.35)$ & $<\mathrm{dl}(0.29)$ & $<\mathrm{dl}(0.18)$ & $52 \pm 23$ & & \\
\hline 4 & 10 & 5.5 & $<\mathrm{dl}(0.46)$ & $<\mathrm{dl}(0.32)$ & $<\mathrm{dl}(0.0)$ & $<\mathrm{dl}(0.03)$ & 33 & & \\
\hline 5 & $6.0 \pm 3.2$ & $2.8 \pm 0.8$ & $<\mathrm{dl}(0.74)$ & $1.9 \pm 1.5$ & $1.5 \pm 0.5$ & $<\mathrm{dl}(0.11)$ & $27 \pm 17$ & & \\
\hline PDD1998 & $13 \pm 7$ & $14 \pm 8$ & $2.7 \pm 2.6$ & $6.9 \pm 6.0$ & $18 \pm 14$ & & $8 \pm 7$ & & \\
\hline $\begin{array}{l}\text { Voisin et } \\
\text { al. } 2000\end{array}$ & & & & & & & & & \\
\hline
\end{tabular}

\subsection{Measured and theoretical Gas/liquid partitioning}

The molar partitioning of a chemical compound $X$ between interstitial gaseous phase and condensed phases $\left(R_{x}\right)$ can be expressed as:

$R_{x}=100 \frac{[X]_{\text {liq }}}{[X]_{\text {liq }}+[X]_{\text {int,gas }}}$

Where $l i q$ refers to the liquid phase (collected in the CDI), int, gas to the interstitial gas phase (from the RJI+mist chamber) and all concentrations are in $\mathrm{nmol} \mathrm{m}^{-3}$. $R_{x}$, therefore, is the fraction (in \%) of the compound in the liquid phase.

Chloride, nitrate, $\mathrm{S}^{\mathrm{IV}}$ and oxalate are predominantly in the liquid phase while acetate, formiate, and $\mathrm{NH}_{3}$ are in the interstitial phase (Table 4). It is interesting to note that very little variation is found among the different cloud events.
These results are similar to those observed by Voisin et al. (2000) for carboxylic acids, chloride and nitrate. On the contrary, in our study, partitioning between $\mathrm{NH}_{3}$ and liquid $\mathrm{NH}_{4}^{+}$is clearly shifted to the gas phase with $62 \%$ of the species present as $\mathrm{NH}_{3}$. This gas contribution is higher than what was found by Voisin et al. (2000), Kasper and Puxbaum (1998) and Fuzzi et al. (1994) but similar to measurements of Laj et al. (2001) at PDD. The partitioning of sulfur species is clearly shifted towards the condensed phase. Such an enrichment of the liquid phase is neither found by Fuzzi et al. (1994), nor by Facchini et al. (1992), who rather found a high gas-phase contribution. The reason for this feature could lay in the fact that the $\mathrm{SO}_{2}$ concentrations are much higher at Kleiner Feldberg and Po Valley where these latter studies were performed, than at Puy de Dôme, where they were lower than the detection limit for most samples. 
Table 4a. Measured Liquid/total fractions $R_{x}(\%)$ from MC and CDI concentrations. Ranges take into account the $30 \%$ and $50 \%$ uncertainty on CDI and MC concentrations, respectively. When gas concentrations are below dl, the $R_{x}$ higher limit is $100 \%$

\begin{tabular}{cccccccc}
\hline Event & $\mathrm{CH}_{3} \mathrm{COO}^{-}$ & $\mathrm{HCOO}^{-}$ & $\mathrm{Cl}^{-}$ & $\mathrm{NO}_{3}^{-}$ & $\mathrm{S}^{\mathrm{IV}}$ & $\mathrm{C}_{2} \mathrm{O}_{4}^{2-}$ & $\mathrm{NH}_{4}^{+}$ \\
\hline 1 & $8.1(4-19)$ & $16(8-33)$ & $51(33-73)$ & $93(87-97)$ & $67(49-84)$ & $39(23-63)$ & $39(23-63)$ \\
2 & $11.5(6-25)$ & $25(13-46)$ & $93(85-100)$ & $99.5(99-100)$ & $93(86-97)$ & $80(65-100)$ & $62(43-81)$ \\
3 & $7.5(4-17)$ & $14.1(7-30)$ & $76(59-100)$ & $92(84-100)$ & $43(23-66)$ & $42(25-100)$ & $12.5(6-27)$ \\
4 & $14.5(7-31)$ & $25(13-46)$ & $94(89-100)$ & $97.7(95-100)$ & $100(79-100)$ & $90(80-100)$ & $38(22-27)$ \\
5 & $2010-39$ & $26(14-48)$ & $84(72-100)$ & $88(78-95)$ & $57(38-77)$ & $69(51-100)$ & $35(20-62)$ \\
$\begin{array}{c}\text { Voisin et } \\
\text { al. (2000) }\end{array}$ & 10 & 10 & 80 & 90 & & & 90 \\
$\begin{array}{c}\text { Kasper and } \\
\text { Puxbaum, (1998) }\end{array}$ & & & & 39 & 54 & & 56 \\
\hline
\end{tabular}

Table 4b. Theoretical liquid/total fractions $R_{x}(\%)$ calculated from the effective Henry's law constant $\mathrm{H}^{*}$. Ranges take into account the uncertainty on the Henry's law constant variability in the literature (see Table 5) as well as its temperature dependence variability, and also the uncertainty of one unity of $\mathrm{pH}$

\begin{tabular}{cccccccc}
\hline Event & $\mathrm{CH}_{3} \mathrm{COO}^{-}$ & $\mathrm{HCOO}^{-}$ & $\mathrm{Cl}^{-}$ & $\mathrm{NO}_{3}^{-}$ & $\mathrm{S}^{\mathrm{IV}}$ & $\mathrm{C}_{2} \mathrm{O}_{4}^{2-}$ & $\mathrm{NH}_{4}^{+}$ \\
\hline 1 & $24(16-46)$ & $50(20-71)$ & 100 & 100 & $3(1.0-9)$ & 100 & $96(89-99)$ \\
2 & $32(26-52)$ & $50(28-68)$ & 100 & 100 & $3.5(1.2-10)$ & 100 & $99(98-100)$ \\
3 & $56(36-84)$ & $88(68-96)$ & 100 & 100 & $3.8(1.3-11)$ & 100 & $87(69-95)$ \\
4 & $59(34-87)$ & $91(59-97)$ & 100 & 100 & $3.2(1.1-10)$ & 100 & $81(56-93)$ \\
5 & $11(8-21)$ & $22(10-39)$ & 100 & 100 & $2.8(0.9-8)$ & 100 & $91(84-96)$ \\
\hline
\end{tabular}

It is possible to investigate whether the measured partitioning corresponds to that predicted by Henry's law equilibrium. This calculation accounts for thermodynamic equilibrium and for the dissolution of species in the liquid phase (Table 5) and formally leads to an effective Henry's law constant (i.e. $\mathrm{H}^{*}$ ). All enthalpies and equilibrium constants are corrected for temperature effects according to Van't Hoff equation, taking $\mathrm{pH}$ into consideration (except for oxalic acid for which the reaction enthalpy is not available in the current literature). The range on the theoretical partitioning calculated in Table 5 are derived both from the uncertainty on $\mathrm{pH}$ and from the uncertainty on the Henry's law constant found in the literature. In order to compare theoretical and measured partitioning of chloride, soluble volatile chloride sampled with mist chambers has been considered, in this section, to be mainly $\mathrm{HCl}$.

The theoretical and measured $\mathrm{R}_{\mathrm{Cl}}, \mathrm{R}_{\mathrm{NO}_{3}}$, and $\mathrm{R}_{\mathrm{ox}}$ are close to $100 \%$, showing that most of the mass lies in the liquid phase. According to this calculation, all three species can, therefore, be considered at Henry's law equilibrium, within analytical uncertainty and instrumental errors. This result is especially interesting for oxalic acid since it is the first experimental determination of its phase partitioning in clouds. Since our measurements of gaseous $\mathrm{HNO}_{3}$ and $\mathrm{HCl}$ are lower limits, there is a possibility for these species to be sub-saturated in the liquid phase.
Monocarboxylic acids and $\mathrm{NH}_{4}^{+}$exhibit a deficit in the liquid phase as compared to theoretical values. For $\mathrm{NH}_{4}^{+}$, such sub-saturation of the liquid phase was already observed in Voisin et al. (2000). The subsaturation of the liquid phase is likely resulting from mass transfer limitation between gaseous and liquid phase as proposed by Ricci et al. (1998) and Winiwarter et al. (1994). However, we observe that for higher $\mathrm{pH}$, both theoretical and measured liquid fraction of $\mathrm{NH}_{3} / \mathrm{NH}_{4}^{+}$decreases.

On the other hand, $\mathrm{S}^{\mathrm{IV}}$ is supersaturated in the liquid phase showing between 43 and $100 \%$ of the $\mathrm{S}^{\mathrm{IV}}$ in the liquid phase as opposed to the expected 2.8 to $3.8 \%$. The apparent supersaturation of the liquid phase could be due to the fact that our measurements of interstitial gaseous $\mathrm{S}^{\mathrm{IV}}$ are, as already mentioned, a lower limit and most of the time under the detection limit. The apparent super-saturation of the liquid phase could also be due to a high amount of HCHO-bound $\mathrm{S}^{\mathrm{IV}}$ (HMSA). Measuring formaldehyde in order to evaluate if this hypothesis explains all of the apparent surper-saturation should be done in further work.

\subsection{Degassing efficiencies upon droplet evaporation}

Significant amounts of $\mathrm{SO}_{2}, \mathrm{HNO}_{3}, \mathrm{HCOOH}, \mathrm{HCHO}$ and $\mathrm{H}_{2} \mathrm{O}_{2}$ evaporating from cloud droplets have been measured directly behind a CVI inlet (Flossmann, 1998; Laj et al., 2001; Noone et al, 1991). Cape et al. (1997) estimated that as 
Table 5. Solubilisation and dissociation constants used in the calculations of the Henry's equilibrium shown in Table 4b. (1)R. Sanders, Compilation of Henry's law constants for inorganic and organic species of potential importance in environmental chemistry, 1999, available at http://diotima.mpch-mainz.mpg.de/ sander/res/henry.html ranges correspond to the 25ile and 75ile on the compiled data (2) Marsh and Mc Elroy, 1985 (3) Jacob, 1986 (4) Chameides, 1984 (5) Weast, 1984

\begin{tabular}{|c|c|c|c|}
\hline Solubilisation & 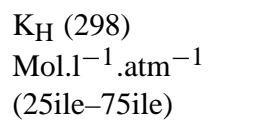 & $\begin{array}{l}-\Delta \mathrm{H} / \mathrm{R} \\
\mathrm{K} \\
(25 \text { ile-75ile })\end{array}$ & Ref \\
\hline $\mathrm{HCl}(\mathrm{g}) \rightleftharpoons \mathrm{Hcl}(\mathrm{l})$ & $15-19$ & $2000-9000$ & (1) \\
\hline $\mathrm{HCOOH}(\mathrm{g}) \rightleftharpoons \mathrm{HCOOH}(\mathrm{l})$ & $4 \times 10^{3}-5.9 \times 10^{3}$ & 5700 & (1) \\
\hline $\mathrm{CH}_{3} \mathrm{COOH}(\mathrm{g}) \rightleftharpoons \mathrm{CH}_{3} \mathrm{COOH}(\mathrm{l})$ & $5.2 \times 10^{3}-8.8 \times 10^{3}$ & $6300-6400$ & (1) \\
\hline $\mathrm{HNO}_{3}(\mathrm{~g}) \rightleftharpoons \mathrm{HNO}_{3}(\mathrm{~L})$ & $1.8 \times 10^{5}-8 \times 10^{5}$ & 8700 & (1) \\
\hline $\mathrm{SO}_{2}(\mathrm{~g}) \rightleftharpoons \mathrm{SO}_{2}(\mathrm{l})$ & $1.2-1.23$ & $2900-3100$ & (1) \\
\hline $\mathrm{H}_{2} \mathrm{C}_{2} \mathrm{O}_{4}(\mathrm{~g}) \rightleftharpoons \mathrm{H}_{2} \mathrm{C}_{2} \mathrm{H}_{4}(\mathrm{l})$ & $1.3 \times 10^{8}-3.8 \times 10^{8}$ & - & (1) \\
\hline $\mathrm{NH}_{3}(\mathrm{~g}) \rightleftharpoons \mathrm{NH}_{3}(\mathrm{l})$ & $56-61$ & $3925-4200$ & (1) \\
\hline Dissociations & 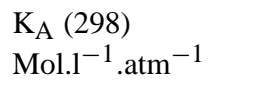 & $\begin{array}{l}-\Delta \mathrm{H} / \mathrm{R} \\
\mathrm{K}\end{array}$ & Ref \\
\hline $\mathrm{HCl} \rightleftharpoons \mathrm{H}^{+}+\mathrm{Cl}^{-}$ & 1.7106 & 6889 & (2) \\
\hline $\mathrm{HCOOH} \rightleftharpoons \mathrm{HCOOH}^{-}+\mathrm{H}^{+}$ & $1.810-4$ & 150 & (4) \\
\hline $\mathrm{CH}_{3} \mathrm{COOH} \rightleftharpoons \mathrm{CH}_{3} \mathrm{COO}^{-}+\mathrm{H}^{+}$ & $1.810-5$ & 46 & (4) \\
\hline $\mathrm{HNO}_{3} \rightleftharpoons \mathrm{NO}_{3}^{-}+\mathrm{H}^{+}$ & 22 & - & (4) \\
\hline $\mathrm{SO}_{2}+\mathrm{H}_{2} \mathrm{O} \rightleftharpoons \mathrm{HSO}_{3}^{-}+\mathrm{H}^{+}$ & $1.710-2$ & 2090 & (4) \\
\hline $\mathrm{HSO}_{3}^{-} \rightleftharpoons \mathrm{SO}_{3}^{2-}+\mathrm{H}^{+}$ & $6.310-8$ & 1510 & (4) \\
\hline 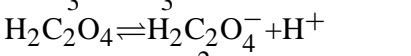 & $5.910-2$ & - & (5) \\
\hline $\mathrm{HC}_{2} \mathrm{O}_{4}^{-} \rightleftharpoons \mathrm{C}_{2} \mathrm{O}_{4}^{2-}+\mathrm{H}^{+}$ & $6.410-5$ & - & (5) \\
\hline $\mathrm{NH}_{3}+\mathrm{H}_{2} \mathrm{O} \rightleftharpoons \mathrm{NH}_{4}^{+}+\mathrm{OH}^{-}$ & $1.710-5$ & 4325 & (3) \\
\hline
\end{tabular}

much as $25 \%$ of the cloud nitrate could be released as $\mathrm{HNO}_{3}$ as cloud droplets evaporated and Laj et al (1998) estimated that 60 to $80 \%$ of the dissolved $\mathrm{HNO}_{3}$ and $\mathrm{NH}_{3}$ is degassing from droplets upon evaporation.

With our experimental set-up, it is possible to estimate the gas fraction that has evaporated from the droplet solute concentration $\left(C_{X g a s}\right)$, which is the fraction that did not undergo irreversible transformation. This is done by calculating the particulate mass concentration difference between CDI (gases+scavenged aerosols) and CVI (residual aerosols only):

$C_{X g a s}=1-\frac{[X]_{\text {part }}\left(\mathrm{nmol} \mathrm{m}^{-3}\right)}{[X]_{l i q}\left(\mathrm{nmol} \mathrm{l}^{-1}\right)^{*} L W C\left(\mathrm{gm}^{-3}\right)^{*} \rho_{l i q}\left(\mathrm{gl}^{-1}\right)}(2)$

Where $[X]_{\text {part }}$ derives from the cascade impactor data behind the CVI and $[X]_{l i q}$ derives from the CDI data.

This calculation is based on subtraction and division of concentrations in the different cloud reservoirs. In order to avoid making comparisons between absolute concentrations in the different cloud reservoirs, we can also work with relative concentrations referred to a given species. In that case, we have chosen $\mathrm{Na}^{+}$as a reference species based on the hypothesis that sodium is conservative and is not present in the gas phase $\left(\left[\mathrm{Na}^{+}\right]_{\text {part }}=\left[\mathrm{Na}^{+}\right]_{l i q}\right)$. Then, $C_{X \text { gas }}$ can be expressed as:

$C_{\text {Xgas }}=1-\frac{\frac{[\mathrm{X}]_{\text {part }}}{\left[\mathrm{Na}^{+}\right]_{\text {part }}}}{\frac{[X]_{\text {liq }}}{\left[\mathrm{Na}^{+}\right]_{\text {liq }}}}$

This calculation method also avoids converting liquid concentrations to atmospheric concentrations and thus limits the artifacts associated to the integration of LWC over the CVI sampling period. The contribution of the gaseous phase to the droplet solute concentration calculated using both relative and absolute concentrations only differs within analytical uncertainties (Table 6). Hereafter, an arithmetic average between both calculation methods will be used. The degassing is extremely variable among gases, ranging from 48.5 to $98 \%$, but quite stable among events.

It is clear that the degassing of acetic and formic acids is quite efficient, as it appears that virtually all $\mathrm{HCOOH}$ and $\mathrm{CH}_{3} \mathrm{COOH}$ dissociated in water evaporates during the dehydration of cloud droplets to aerosols. Chloride shows the highest degassing efficiency of all inorganic species with more than $62 \%$ (and up to $89 \%$ ) of the solute concentration being released as volatile inorganic $\mathrm{Cl}$ during droplet evaporation.

The presence of a high-degassed fraction of dissolved $\mathrm{C}_{2} \mathrm{O}_{4}^{2-}$ is more surprising as this chemical species is rarely 
Table 6. Lower limit of the gaseous contribution to the concentration of cloud droplets, calculated from the CDI and CVI data (\%) in absolute $(\mathrm{Abs})$ as $(\mathrm{CDI}-\mathrm{CVI}) / \mathrm{CDI}$ and in relative $(/ \mathrm{Na})$ as $\left(\mathrm{CDI}_{\mathrm{Na}}-\mathrm{CVI}_{\mathrm{Na}}\right) / \mathrm{CDI} \mathrm{Na}$

\begin{tabular}{cccccccccccccccc}
\hline \multirow{2}{*}{ Event } & \multicolumn{2}{c}{$\mathrm{CH}_{3} \mathrm{COO}^{-}$} & \multicolumn{2}{c}{$\mathrm{HCOO}^{-}$} & \multicolumn{2}{c}{$\mathrm{Cl}^{-}$} & \multicolumn{2}{c}{$\mathrm{NO}_{3}^{-}$} & \multicolumn{3}{c}{$\mathrm{S}^{\mathrm{IV}}+\mathrm{S}^{\mathrm{VI}}$} & \multicolumn{2}{c}{$\mathrm{C}_{2} \mathrm{O}_{4}^{2-}$} & \multicolumn{2}{c}{$\mathrm{NH}_{4}^{+}$} \\
& $\mathrm{Abs}$ & $/ \mathrm{Na}$ & $\mathrm{Abs}$ & $/ \mathrm{Na}$ & $\mathrm{Abs}$ & $/ \mathrm{Na}$ & $\mathrm{Abs}$ & $/ \mathrm{Na}$ & $\mathrm{Abs}$ & $/ \mathrm{Na}$ & $\mathrm{Abs}$ & $/ \mathrm{Na}$ & $\mathrm{Abs}$ & $/ \mathrm{Na}$ \\
\hline 1 & 98 & - & 98 & - & 93 & - & 42 & - & 40 & - & 63 & - & 49 & - \\
-2 & 95 & 94 & 93 & 90 & 91 & 87 & 69 & 58 & 39 & 16 & 70 & 58 & 58 & 42 \\
3 & 97 & 99 & 97 & 98 & - & - & 12 & 57 & 18 & 59 & 32 & 66 & 19 & 60 \\
4 & 98 & 98 & 99 & 99 & 57 & 67 & 43 & 56 & 45 & 58 & 56 & 66 & 40 & 54 \\
5 & 98 & 98 & 97 & 98 & 87 & 91 & 67 & 78 & 38 & 58 & 68 & 78 & 48 & 65 \\
Median & 97,7 & 98,4 & 96,8 & 97,8 & 82,0 & 81,7 & 42,6 & 57,2 & 39,4 & 57,6 & 63,0 & 66,2 & 48,4 & 57,2 \\
\hline
\end{tabular}

found in the gas phase. The presence of $\mathrm{C}_{2} \mathrm{O}_{4}^{2-}$ in the liquid phase can be due to its production from another dissolved gas than $\mathrm{H}_{2} \mathrm{C}_{2} \mathrm{O}_{4}$, or from other particulate carbonaceous species. More work is necessary on that issue but it seems clear that not all oxalic acid present in the liquid phase is found as a particulate residue.

Similarly to carboxylic acids, a large fraction of dissolved $\mathrm{NH}_{3}$ returns back to the gas phase upon evaporation. The amount of degassed $\mathrm{NH}_{3}$ accounts for $52.8 \%$ of the dissolved fraction. This could be surprising, considering the fact that residual aerosols are acidic, and the liquid phase is sub-saturated.

Because little $\mathrm{SO}_{4}^{2-}$ (in the form of $\mathrm{H}_{2} \mathrm{SO}_{4}$ ) would be thermodynamically expected to evaporate from dehydrated cloud droplets, the apparent evaporation of $\mathrm{SO}_{4}^{2-}$ from liquid droplets to cloud particulate residues is likely due to evaporation of $\mathrm{S}^{\mathrm{IV}}$ and not $\mathrm{H}_{2} \mathrm{SO}_{4}$. Between 27 and $52 \%$ of $\mathrm{S}^{\mathrm{IV}}$ present in the liquid phase degasses upon droplet evaporation. This high percentage confirms the fact that at least a fraction of $S^{\mathrm{IV}}$ dissolved in cloud droplets are oxidized (after sampling) in the bulk samples from the CDI but evaporates in the CVI. 27-52\% degassing is relatively high considering the importance of the particulate phase and indicates that the amount of $\mathrm{SO}_{2}$ converted to $\mathrm{SO}_{4}^{2-}$ is limited. This is certainly due to limited oxidant levels in the wintertime and presumably to a high amount of $\mathrm{S}^{\mathrm{IV}}$ present in a complexed form with HCHO (HMSA). Only one sample (sample 2) shows reduced degassing of $\mathrm{SO}_{2}$ due to potential $\mathrm{SO}_{2}$ oxidation. This sample is clearly influenced by anthropogenic activities as shown by the elevated concentrations of sulfate, nitrate, ammonium and carboxylic acids and the low $\mathrm{pH}$. Unfortunately, we do not have an indication on $\mathrm{H}_{2} \mathrm{O}_{2}$ levels to understand what favored $\mathrm{S}^{\mathrm{VI}}$ formation.

As already mentioned, the stable $\mathrm{NH}_{4}^{+} / \mathrm{SO}_{4}^{2-}$ equivalent ratio in the liquid residual and interstitial phases indicates that any $\mathrm{S}^{\mathrm{IV}}$-to-S $\mathrm{SI}^{\mathrm{VI}}$ conversion is paralleled by $\mathrm{NH}_{3}$ conversion to $\mathrm{NH}_{4}^{+}$upon evaporation, leading to $\left(\mathrm{NH}_{4}\right)_{2} \mathrm{SO}_{4}$ formation in the processed aerosol.

The degassing fraction of $\mathrm{NO}_{3}^{-}$, close to $50 \%$, roughly corresponds to that calculated for $\mathrm{S}^{\mathrm{VI}}$ degassing, and this is confirmed by a rather stable $\mathrm{NO}_{3}^{-} / \mathrm{SO}_{4}^{2-}$ ratio in the liquid and residual phases. However, $\mathrm{NO}_{3}^{-} / \mathrm{SO}_{4}^{2-}$ is twice as low in the interstitial aerosol phase compared to the residual aerosol phase. Because both species are internally mixed in aerosols (Sellegri et al., 2003a), and thus should have similar particulate scavenging efficiencies in cloud droplets (Sellegri et al., 2003b), we propose the hypothesis of a favored cloud processing of nitrate over sulfate under the conditions of the Puy de Dôme.

3.4 Gas/liquid/particulate partitioning and phase origin of the liquid content

The partitioning of $\mathrm{HCOOH} / \mathrm{HCOO}^{-}, \mathrm{CH}_{3} \mathrm{COOH} /$ $\mathrm{CH}_{3} \mathrm{COO}^{-}, \quad \mathrm{HCl} / \mathrm{Cl}^{-}, \quad \mathrm{HNO}_{3} / \mathrm{NO}_{3}^{-}, \quad \mathrm{SO}_{2} / \mathrm{S}^{\mathrm{IV}}$ liq, $\mathrm{H}_{2} \mathrm{C}_{2} \mathrm{O}_{4} / \mathrm{C}_{2} \mathrm{O}_{4}^{2-}$ and $\mathrm{NH}_{3} / \mathrm{NH}_{4}^{+}$between gaseous, liquid and interstitial particulate phases were found to be rather stable over the different cloud events. The averaged repartition over the 5 cloud events is shown Fig. 2. In this figure, degassing efficiencies calculated as above (Eq. 2) are seen as lower limit of the gas contribution of species to the solute concentration.

The major fractions of $\mathrm{CH}_{3} \mathrm{COOH} / \mathrm{CH}_{3} \mathrm{COO}^{-}$and $\mathrm{HCOOH} / \mathrm{HCOO}^{-}$are in the gas phase. Moreover, the limited amount of carboxylic acids present in the liquid phase is essentially originating form the gas phase. No production in the liquid phase seems to take place unless a significant consumption occurs simultaneously, which is unlikely. In fact acetic and formic acids are not found in particulate droplet residues. In that sense, these species contribute to acidification of the liquid phase but do not have a major impact on cloud-processed aerosols.

Contrarily to carboxylic acids, oxalic acid is mainly found in the condensed phase (liquid and interstitial particles). Still, $33 \%$ of the total mass of the compound is found in the gas phase. Also the same percentage of dissolved $\mathrm{C}_{2} \mathrm{O}_{4}^{2-}$ is originating from the gas phase.

Despite its high solubility, a large fraction (67\%) of $\mathrm{NH}_{3}$ lies in the interstitial gaseous phase. This is contrary to the partitioning of this species at Kleiner Felberg (Fuzzi et al., 1994), and could be due to elevated concentrations of $\mathrm{NH}_{3}$, as already measured by Laj and coworkers (2001) using 


\section{$\mathrm{CH}_{3} \mathrm{COOH} / \mathrm{CH}_{3} \mathrm{COO}$}

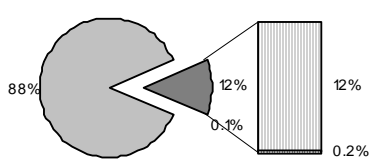

$\mathrm{SO}_{2} / \mathrm{SO}_{4}{ }^{2-}$

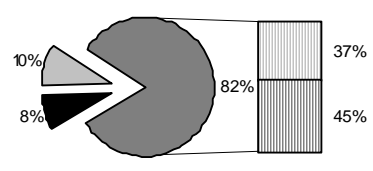

$\mathrm{HCOOH} / \mathrm{HCOO}$

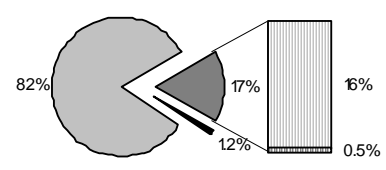

$\mathrm{H}_{2} \mathrm{C}_{2} \mathrm{O}_{4} / \mathrm{C}_{2} \mathrm{O}_{4}{ }^{2-}$

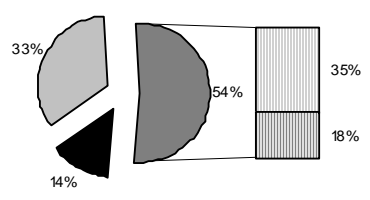

$\mathrm{HCl} / \mathrm{Cl}$

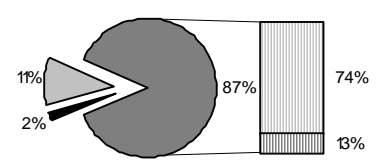

$\mathrm{NH}_{3} / \mathrm{NH}_{4}^{+}$

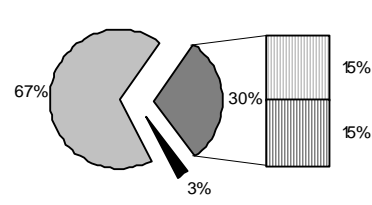

$\mathrm{HNO}_{3} / \mathrm{NO}_{3}$

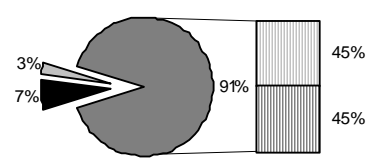

Interstitial gas

Interstitial particles

Liquid phase

gas-originating Liq.

part-originating Liq.

Fig. 2. Phase partitioning between the gas, particulate and liquid phases in cloud calculated from concentrations from the RJI+Cascade Impactor (particulate), RJI+Mist chambers (intertitial gaz phase) and CDI (liquid phase). Further partitioning within the liquid phase between the gas-originating fraction and the particle-originating fraction are calculated from the CVI/CDI comparison. Gas concentrations are below detection limits for $\mathrm{HCL}, \mathrm{HNO}_{3}, \mathrm{SO}_{2}$ and $\mathrm{H}_{2} \mathrm{C}_{2} \mathrm{O}_{4}$, and thus their concentration are assimilated to detection limits.

different techniques. Consequently, as much as half of dissolved $\mathrm{NH}_{4}^{+}$originates from the gas phase. Our results show that a high $\mathrm{pH}$, this contribution is lower, as expected from thermodynamics. The studies of Laj et al. (1997) and Winiwarter et al. (1994), showed that $\mathrm{NH}_{4}^{+}$subsaturation increases with increasing $\mathrm{pH}$. The $\mathrm{pH}$ dependence of the subsaturation could be an artifact resulting from the fact that transfer through nucleation scavenging is not $\mathrm{pH}$ dependent.

All other inorganic species are mostly found in the condensed phase with an interstitial gas fraction of the total mass smaller than $11 \%$. The origin of the liquid phase fraction varies depending on the chemical compound. The contribution to liquid concentration from particulate phase is lowest for $\mathrm{Cl}^{-}(14 \%)$. The contribution from the particulate phase is higher for $\mathrm{SO}_{4}^{2-}$ and $\mathrm{NO}_{3}^{-}$(about 50\%). This is not surprising given their elevated concentration in the particulate phase, which could limit the gas dissolution.

\section{Summary and conclusions}

The study of the behavior of several key atmospheric compounds was performed using complementary sampling inlets, in the interstitial, residual and liquid phases of a multiphase system. Partitioning of $\mathrm{HCOOH} / \mathrm{HCOO}^{-}$, $\mathrm{CH}_{3} \mathrm{COOH} / \mathrm{CH}_{3} \mathrm{COO}^{-}, \mathrm{HCl} / \mathrm{Cl}^{-}, \mathrm{HNO}_{3} / \mathrm{NO}_{3}^{-}, \mathrm{SO}_{2} / \mathrm{S}^{\mathrm{IV}}$ / $\mathrm{S}^{\mathrm{IV}}, \mathrm{H}_{2} \mathrm{C}_{2} \mathrm{O}_{4} / \mathrm{C}_{2} \mathrm{O}_{4}^{2-}$ and $\mathrm{NH}_{3} / \mathrm{NH}_{4}^{+}$on the site of the Puy de Dôme, for 5 cloud events was examined. Despite the fact that liquid concentrations varied over a large ranges, phase partitioning of the different species show very consistent figures for the different cloud events, tending to show that at- mospheric processes can successfully be studied with this methodology.

In agreement with the thermodynamic predictions, $\mathrm{HCl} / \mathrm{Cl}^{-}$is mainly present in the liquid phase, as the result of volatile gaseous chloride for $80 \%$ of the liquid concentration. $\mathrm{S}^{\mathrm{IV}}+\mathrm{S}^{\mathrm{VI}}$ is also mainly present in the condensed phase and especially in the liquid phase of droplets, as the result of high amounts of particulate $\mathrm{SO}_{4}^{2-}$ transferred to the liquid phase by nucleation scavenging, but also for $48 \%$ of the liquid concentration as the result of $\mathrm{SO}_{2}$ dissolution. This high dissolution of $\mathrm{S}^{\mathrm{IV}}$ leads to a super-saturation of the liquid phase with respect to the $\mathrm{SO}_{2}$ atmospheric level, which is of the order of $200 \mathrm{ppt}$ at Puy de Dôme during winter.

$\mathrm{HNO}_{3} / \mathrm{NO}_{3}^{-}$also mainly lies in the liquid phase, in equilibrium with the predictions from Henrys law. About $50 \%$ of the liquid phase $\mathrm{NO}_{3}^{-}$evaporates back to the gas phase, indicating that at least this fraction of the liquid $\mathrm{NO}_{3}^{-}$originates from dissolved $\mathrm{HNO}_{3}$. In fact, there are indications that the contribution of dissolved $\mathrm{HNO}_{3}$ to the concentration of the droplets should be higher than these $50 \%$, as a clear $\mathrm{NO}_{3}^{-}$ enrichment of the residual aerosol phase is observed relative to $\mathrm{SO}_{4}^{2-}$ and $\mathrm{NH}_{4}^{+}$, compared to the interstitial aerosols. Incloud gas-to-particle transfer of $\mathrm{HNO}_{3}$ possibly plays a key role in aerosol acidification and in the modification of their hygroscopic properties (Sellegri at al. 2003b).

Despite its high solubility, a large fraction $(67 \%)$ of $\mathrm{NH}_{3}$ lies in the interstitial gaseous phase and only half of liquid $\mathrm{NH}_{4}^{+}$originates from the gas phase. This leads to a clear deviation from Henry's law equilibrium and to the subsaturation of the liquid phase, presumably due to mass transfer limitation. Assuming Henry's law equilibrium would 
overestimate wet deposition. Contrary to the conditions encountered in the Po Valley fog (Ricci et al., 1998), particulate ammonium does not compensate for dissolved $\mathrm{NH}_{3}$ to reach equilibrium. Gaseous $\mathrm{NH}_{3}$, which seems to be in higher concentrations than in other high altitude sites, therefore plays a key role in neutralizing cloud droplets at Puy de Dôme.

The major fractions of $\mathrm{CH}_{3} \mathrm{COOH} / \mathrm{CH}_{3} \mathrm{COO}^{-}$and $\mathrm{HCOOH} / \mathrm{HCOO}^{-}$are in the gas phase as well. Moreover, the limited amount of carboxylic acids present in the liquid phase is essentially originating form the gas phase. The apparent sub-saturation of the liquid phase is, again, presumably due to mass transfer limitation. Oxalic acid is mainly found in the condensed phase (liquid and interstitial particles) but dissolved $\mathrm{C}_{2} \mathrm{O}_{4}^{2-}$ surprisingly originates mainly from the gas phase.

Overall, gas contribution to the droplet solute concentration ranges from at least $50 \%$ to $98 \%$ depending on the chemical species. This is particularly important considering that aerosol scavenging efficiencies are often calculated assuming a negligible gas-phase contribution to the solute concentration. This can lead to significant overestimation of nucleation scavenging especially for carboxylic acids.

Acknowledgements. This work was supported by CNRS-INSU under the National Program for Atmospheric Research (PNCA), by the Ministère de la Recherche under ACI-Jeune Chercheur to PL, and by the Scientific council of Région d'Auvergne.

\section{References}

Audiffren, N., Buisson, E., and Chaumerliac, N.: Deviations from Hemry's law equilibrium for chemical species in a polydisperse cloud: The oxidizing capacity of the troposphere, Venice, European Commission, 1996.

Baltensperger, U., Schwikowski, M., Jost, D. T., Nyeki, S., Gäggeler, H. W., and Poulida, O.: Scavenging of atmospheric constituents in mixed phase clouds at the high-alpine site Jungfraujoch Part I: Basic concept and aerosol scavenging by clouds, Atm. Env., 32(23), 3975-3983, 1998.

Cape, J. N., Hargreaves, K. L., Storeton-West, R. L., Jones, B., Davies, T., Colvile, R. N., Gallagher, M. W., Choularton, T. W., Pahl, S., Berner, A., Kruisz, C., Bizjak, M., Laj, P., Facchini, M. C., Fuzzi, S.,. Arends, B. G, Acker, K., Wieprecht, W., Harrison, R. M., and Peak, J. D.: The budget of oxidized nitrogen species in orographic clouds, Atm. Env., 31(16), 2625-2636, 1997.

Chameides, W. L.: The photochemistry of a remote marine stratiform cloud, J. Geophys. Res., 89, 4739-4755, 1984.

Facchini, M. C., Fuzzi, S., Kessel, M., Wobrock, W., Jaeschke, W., Arends, B. G., Möls, J. J., Berner, A., Solly, I., Kruisz, C., Reischl, G., Pahl, S., Hallberg, A., Ogren, J. A., FierlingerOberlinninger, H., Marzorati, A., and Schell, D.: The chemistry of sulfur and nitrogen species in a fog system. A multiphase approach, Tellus 44B, 505-521, 1992a.

Facchini, M. C., Fuzzi, S., Lind, J. A., Kessel, M., FierlingerOberlinninger, H., Kalina, M., Puxbaum, H., Winiwarter, W., Arends, B. G., Wobrock, W., Jaeschke, W., Berner, A., and Kruisz, C.: Phase partitioning and chemical reactions of low molecular weight organic compounds in fog, Tellus 44B, 533544, 1992 b.

Flossmann, A. I.: A 2-D spectral model simulation of the scavenging of geaseous and particulate sulfate by a warm marine cloud, Atmospheric Research, 32, 233-248, 1994.

Flossmann, A. I.: Interaction of aerosol particles and clouds, J. Atmos. Sciences, 55, 879-887, 1998.

Flossmann, A.: Cloud Ice Mountain Experiement (CIME) Final Report, Aubière, France, Laboratoire de Météorologie Physique, 2000.

Fuzzi, S., Facchini, M. C., Schell, D., Wobrock, W., Winkler, P., Arends, B. G., Kessel, M., Möls, J. J., Pahl, S., Schneider, T., Berner, A., Solly, I., Kruisz, C., Kalina, M., Fierlinger, H., Hallberg, A., Vitali, P., Santoli, L., and Tigli, G.: Multiphase chemistry and acidity of clouds at Kleiner Feldberg, J. Atmos. Chem., 19, 87-106, 1994.

Hitzenberger, R., Berner, A., Kromp, R., Kasper-Giebl, A., Limbeck, A., Tscherwenka, W., and Puxbaum, H.: Black carbon and other species at a high-elevation European site (Mount Sonnblick, 3106 m, Austria): Concentrations and scavenging efficiencies, Journal of Geophysical Research, 105(D20), 24637 24645, 2000.

Husain, L., Rattigan, O. V., Dutkiewicz, V. A., Das, M., Judd, C. D., Khan, A. R., Richter, R., Balasubramanian, R., Swami, K., and Walcek, C. J.: Case studies of the $\mathrm{SO}_{2}+\mathrm{H} 2 \mathrm{O} 2$ reaction in clouds, Journal of Geophysical Research, 105(D8), 9831-9841, 2000.

Jaffrezo, J.-L., Calas, N., and Bouchet, M.: Carboxylic acid measurements with ionic chromatography, Atm. Env., 32, 27052708, 1998.

Kasper, A. and Puxbaum, H.: Seasonal variation of $\mathrm{SO}_{2}$, $\mathrm{HNO}_{3}, \mathrm{NH}_{3}$, and selected aerosol components at sonnblick (3106 m a.s.1.), Atm. Env., 32(23), 3925-3939, 1998.

Kasper-Giebl, A., Kalina, M. F., and Puxbaum, H.: Scavenging ratios for sulfate, ammonium and nitrate determined at Mt. Sonnblick (3106 m a.s.1.), Atm. Env., 33, 895-906, 1999.

Kasper-Giebl, A., Koch, A., Hitzenberger, R., and Puxbaum, H.: Scavenging Efficiency of "Aerosol carbon" and Sulfate in Supercooled Clouds at Mt. Sonnblick (3106 m a.s.1., Austria), Journal Atmospheric Chemistry, 35, 33-46, 2000.

Keene, W. C., Mosher, B. W., Jacob, D. J., Munger, J. W., Talbot, R. W., Artz, R. S., Maben, J. R., Daube, B. C., and Galloway, J. N.: Carboxylic acids in clouds at a high-elevation forested site in Central Virginia, J. Geophys. Res., 100(D5), 9345-9357, 1995.

Krämer, M., Schüütz, L, Elbert, W, and Beltz, N: Cloud processing of continental aerosol particles: Experimental investigations for different drop sizes, J. Geophys. Res., 105(D9), 11 739-11 752, 2000.

Kruisz, C., Berner, A., and Branntner, B: A cloud water sampler for high wind speeds, Borell, P. M., Borell, P., Cvitas, T., Seiler, W. (Eds), Proc. EUROTRAC Symp. '92, SPB Academic Publishing bv, pp. 523-525, The Hague, 1993.

Kulmala, M., Korhonen, P., Laaksonen, A., and Vesala, T.: Changes in cloud properties due to $\mathrm{NO}_{\mathrm{x}}$ emissions, Geophys. Res. Lett., 22(3), 239-242, 1995.

Laj, P., Flossmann, A. I., Wobrock, W., Fuzzi, S., Orsi, G., Ricci, L., Mertes, S., Schwarzenböck, A., Heintzenberg, J., and Ten Brink, H.: Behaviour of $\mathrm{H}_{2} \mathrm{O}_{2}, \mathrm{NH}_{3}$, and black carbon in mixed-phase clouds during CIME, Atm. Res., 58(4), 315-336, 2001.

Laj, P., Fuzzi, S., Lazzari, A., Ricci, L., Orsi, G., Berner, A., 
Schell, D., Günther, A., Wendisch, M., Wobrock, W., Frank, G., Martinsson, B., and Hillamo, R.: The size-dependent chemical composition of fog drops, Contr. Atmos. Phys., 71(1), 115-130, 1998.

Laj, P., Fuzzi, S., Facchini, M. C., Lind, J. A., Orsi, G., Preiss, M., Maser, R., Jaeschke, W., Seyffer, E., Arends, B. G., Mols, J. J., Acker, K., Wieprecht, W., Moller, D., Colvile, R. N., Gallagher, M. W., Beswick, K. M., Hargreaves, K. J., Storeton-West, R. L., and Sutton, M. A.: Cloud processing of soluble gases, Atmospheric Environment, 31(16), 2589-2598, 1997.

Lawrence, M. G. and Crutzen, P. J.: The impact of cloud particle gravitational settling on soluble trace gas distribution, Tellus 50B(3), 263-289, 1998.

Lelieveld, J. and Crutzen, P. J.: The role of clouds in tropospheric photochemistry, J. Atmos. Chem, 12, 229-267, 1991.

Limbeck, A. and Puxbaum, H.: Dependence of in-cloud scavenging of polar organic aerosol compounds on the water solubility, JGR 105(D15), 19857-19867, 2000.

Marsh, A. R. W. and Mc Elroy, W. J.: The dissociation constant nad Henry's law constant of HCL in aqueous solution, Atm. Env., 19, 1075-1080, 1985.

Munger, J. W., Jacob, D. J., Daube, B. C., Horowitz, L. W., Keene, W. C., and Heikes, B. G.: Formaldehyde, glyoxal, and methylglyoxal in air and cloudwater at a rural mountain site in central Virginia, J. Geophys. Res., 100D, 9325-9333, 1995.

Neuman, J. A., Huey, L. G., Ryerson, T. B., and Fahey, D. W.: Study of inlet materials for sampling atmospheric nitric acid, Environ. Sci. Technol., 33, 1133-1136, 1999.

Noone, K. J., Ogren, J. A., Noone, K. B., Hallberg, A., Fuzzi, S., and Lind, J. A.: Measurements of the partitioning of hydrogen peroxide in a stratiform cloud, Tellus 43B, 280-290, 1991.

Ogren, J. A. and Charlson, R. J.: Implications for models and measurements of chemical inhomogeneities among cloud droplets, Tellus 44B, 208-225, 1992.

Ogren, J. A., Noone, K. J., Hallberg, A., Heintzenberg, J., Schell, D., Berner, A., Solly, I., Kruisz, C., Reischl, G., Arends, B. G., and Wobrock, W.: Measurements of the size dependence of the concentration of non-volatile material in fog droplets, Tellus 44B, 570-580, 1992.

Ogren, J. A., Heintzenberg, J., and Charlson, R. J.: In-situ sampling of clouds with a droplet to aerosol converter, Geophys. Res. Lett., 12, 121-124, 1985.

Pandis, S. N. and Seinfeld, J. H.: Should bulk cloudwater samples obey Henry's law?, J. Geophys. Res., 96D, 10 791-10 798, 1991.

Pruppacher, H. R. and Klett, J. D.: Microphysics of clouds and precipitation, Dordrecht, Reidel, 1997.

Rao, X. and Collett, J. L.: Behavior of S(IV) and formaldehyde in a chemically heterogeneous cloud, Environ. Sci. Technol., 29, 1023-1031, 1995.

Ricci, L., Fuzzi, S., Laj, P., Lazzari, A., Orsi, G., Berner, A., Günther, A., Arends, B., and Wendisch, M.: Gas/liquid equilibria in polluted fog, Contr. Atmos. Phys., 71(1), 159-170, 1998.

Richards, L. W., Anderson, J. A., Blumenthal, D. L., McDonald, J. A., Kok, G. L., and Lazrus, A. L.: Hydrogen peroxide and sulfur (IV) in Los Angeles cloud water, Atmos. Envir., 17, 911-914, 1983.

Saxena, P. and Hildemann, L. M.: Water-soluble organics in atmospheric particles: A critical review of the literature and application of thermodynamics to identify candidate compounds, J.
Atmos. Chem., 24, 57-109, 1996.

Schell, D., Wobrok, W., Maser, R., Preiss, M., Jaeschke, W., Georgii, H. W., Gallagher, M. W., Bower, K. N., Beswick, K. M., Pahl, S., Facchini, M. C., Fuzzi, S., Wiedensholer, A., Hansson, H. C., and Wendisch, M.: The size -dependent chemical composition of cloud droplets, Atmos. Envir., 1997.

Schwartz, S. E.: Mass-transport consideration pertinent to aqueous phase reactions of gases in liquid water clouds, Chemistry of the Atmospheric Multiphase Systems, Jaeschke, W. (Ed), Heildelberg, Springer-Verlag, 451-471, 1986.

Sellegri, K., Laj, P., Peron, F., Dupuy, R., Legrand, M., Preunkert, S., Putaud, J.-P., Cachier, H., and Ghermandi, G.: Mass balance of winter time free tropospheric aerosol at the Puy de Dôme (France), Journal of Geophysical Research, Vol. 108 , No. D11, DOI 10.1029/2002JD002747, 2003a.

Sellegri, K., Laj, P., Dupuy, R., Legrand, M., Preunkert, S., Putaud, J.-P., and Cachier, H.: Size-dependent scavenging efficiencies of multi-component atmospheric aerosols in clouds, Journal of Geophysical Research, Vol. 108 , No. D11 , DOI 10.1029/2002JD002749, 2003b.

Talbot, R. W., Scheuer, E. M., Lefer, B. L., and Luke, W. T.: Measurements of sulfur dioxide during GASIE with the mist chamber technique, Journal of Geophysical Research, 102, 16273$16278,1997$.

Vocourt, V.: Etalonnage et Simulation numérique d'une Sonde à Impaction Virtuelle (CVI) dans le cadre de l'étude des propriétés physico-chimiques des particules nuageuses, these de doctorat, Clermont Ferrand, Universite Blaise Pascal, 2002.

Voisin, D., Legrand, M., and Chaumerliac, N.: Scavenging of acidic gases $\left(\mathrm{HCOOH}, \mathrm{CH}_{3} \mathrm{COOH}, \mathrm{HNO}_{3}, \mathrm{HCl}\right.$, and $\left.\mathrm{SO}_{2}\right)$ and ammonia in mixed liquid-solid water clouds at the Puy de Dôme mountain, J. Geophys. Res., 105(D5), 6817-6836, 2000.

Warneck, P.: The equilibrium distribution of atmospheric gases between the two phases of liquid water clouds, Chemistry of Multiphase Atmospheric Systems, Jaeschke, W. (Ed), Heidelberg, Springer Verlag, 1986.

Weast, R. C.: Handbook of Chemistry and Physics, Boca Raton, Florida, 1984.

Winiwarter, W., Brantner, B., and Puxbaum, H.: Comments on: Should bulk cloudwater or fogwater samples obey Henry's law? J. Geophys. Res., 97D, 6075-6078, 1992.

Winiwarter, W., Fierlinger, H., Puxbaum, H., Facchini, M. C., Arends, B. G., Fuzzi, S., Schell, D., Kaminski, U., Pahl, S., Schneider, T., Berner, A., Solly, I., and Kruisz, C.: Henry's law and the behaviour of weak acids and bases in fog and cloud, J. Atmos. Chem., 19, 173-188, 1994.

Winiwarter, W., Puxbaum, H., Facchini, M. C., Orsi, G., Beltz, N., Enderle, K., and Jaeschke, W.: Organic acid gas and liquid phase measurements in Po Valley autumn-winter conditions in the presence of fog, Tellus 40B, 348-357, 1988.

Wobrock, W., Flossmann, A. I., Monier, M., Pichon, J.-M., Cortez, L., Fournol, J.-F., Schwarzenböck, A., Mertes, S., Heintzenberg, J., Laj, P., Orsi, G., Ricci, L., Fuzzi, S., Ten Brink, H., Jongejan, P., and Otjes, R.: The Cloud Ice Mountain Experiment (CIME) 1998: experiment overview and modelling of the microphysical processes during the seeding by isentropic gas expansion, Atm. Res., 58, 231-265, 2001

Wobrock, W., Schell, D., Maser, R., Jaeschke, W., Georgii, H.-W., Wieprecht, W., Arends, B. G., Möls, J. J., Kos, G. P. A., Fuzzi, 
S., Facchini, M. C., Orsi, G., Berner, A., Solly, I., Kruisz, C., Svenningsson, I. B., Wiedensohler, A., Hansson, H.-C., Ogren, J. A., Noone, K. J., Hallberg, A., Pahl, S., Schneider, T., Winkler, P., Winiwarter, W., Colvile, R. N., Choularton, T. W., Flossmann, A. I., and Borrmann, S.: The Kleiner Feldberg Cloud Experiment 1990. An overview, J. Atmos. Chem., 19, 3-35, 1994.
Zhang, M. H. and Mc Murry, H.: Evaporative losses of fine particulate nitrates during sampling, Atmos. Env., 26A(18), 3305-3312, 1992. 